\section{Ban on sale may cause Indian blood shortage}

An acute blood shortage is feared in India following the introduction of a Supreme Court order banning the estimated half a million paid blood donors (PBD), who have hitherto provided onethird of the country's supplies ( 3.5 million units), from selling their blood. The ban came into effect on January 1st, 1998. 674 commercial blood banks will now have to close or convert to non-profit making organizations.

Delays in implementing a national voluntary blood do. nation (VBD) pro-

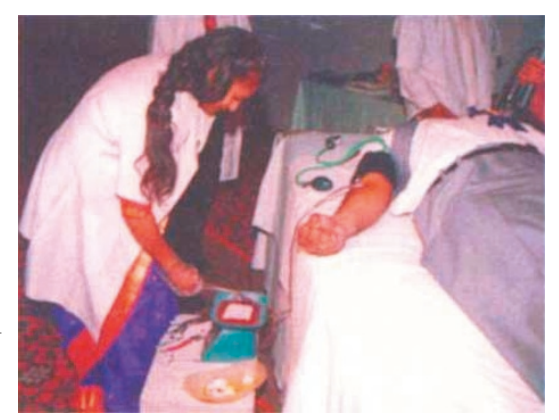

components instead of whole blood. However, previous campaigns have not proven successful: many Indians still fear that blood donation causes weakness and impotence.

VBD could gather momentum through innovative schemes such as that launched recently by $I A B B$ in cooperation with an insurance company. Under this scheme one unit of blood donation is rewarded with $\$ 1300$ accident insurance cover for a year plus a donor card entitling the owner to receive one unit of blood free of gram launched two years ago mean official claims that the remaining 727 government-run blood banks will make up the blood deficit will not be realized. The day that the ban went into force, the blood bank at the government-run Hindu Rao hospital, Delhi, reported that it could not find a single volunteer donor.

Vinod Behari Lal, president of the Indian Association of Blood Banks (IABB), says India is not ready for complete VBD. "The two-year deadline given by the Indian court to switch to VBD is too short considering it took the United States five years to make the switch and Malaysia ten years," he argues. Jagdish Bharadwaje president of the Fellowship of Blood donors-an organization representing PBDs-protests that Germany allows paid donors even today. "In India PBDs had been contributing to health care since 1942," he says. "Just throwing them out in the cold after having sucked their blood for 55 years is a violation of human rights."

The new law calls for the creation of a National Blood Transfusion Council (NBTC) to regulate blood banking in an effort to clean up the nation's blood supply, but it is accused of being slow to react to the Supreme Court deadline. "The council, headed by a part time chairman, held just four meetings in two years and did very little to promote VBD through education campaign," says IABB secretary, Divya Lal. NBTC president, JVR Prasad Rao, estimates that the shortfall will not exceed 10 percent and there is no cause for panic. He plans to increase voluntary donation through advertisement campaigns and by educating doctors on the use of blood charge, if needed. IABB has 800 policy holders and the number is growing.

The VBD program was set up by the health ministry in an attempt to reduce supplies contaminated with hepatitis B and HIV. This need was highlighted by a 1989 National Aids Control Organization (NACO) survey, which concluded that many paid donors belonged to poor social strata, were drug addicts and donated blood frequently at several banks. However, the concern that paid donors are more likely to pass on contaminated blood has not been corroborated. A 1996 analysis of data from Delhi's five AIDS surveillance centers revealed HIV prevalence in voluntary donors to be 0.43 percent compared with 0.31 percent in PBDs.

According to Divya Lal, no one has raised this incongruity before the Supreme Court, which based its order on a survey of only 120 paid donors from 12 cities. The survey was carried out by Ferguson \& Co, a firm of chartered accountants, which some claim has been influenced by a worldwide movement away from paid donation.

K.S. Jayaraman, New Dehli

\section{Germany still pays donors}

Although a European Commission (EC) as far back as 1989 recommended that every country should cover its own blood needs without paid donation, 20 percent of Germany's supplies still come from paid donors. They prefer to see the fee as a reimbursement of expenses rather than a payment.

The amount paid for donation differs between blood collecting organizationsUniversities, clinics and private companies. For a straightforward blood donation, the donor can expect to receive around 50DM (US\$30). Donating platelets or plasma can be more profitable at around 100DM.

Thomas Herzfeld of the German Red Cross (DRK) unit in Nordrhein Westfalia (the largest unit in the country), told Nature Medicine that "Germany has not created a positive atmosphere: blood donors are not yet seen as lifesavers. Often they are seen as stupid people that give something valuable away for nothing." Herzfeld says that even if Germany obtained enough non-paid donated blood for its needs, it would still have to import plasma and other blood cells, which come largely from the US.

Within Germany, even the DRK is perceived as making money on the sale of voluntary donations (around 170DM per blood storage). But Herzfeld insists that as a charitable organization, DRK does not make a profit. "The equipment and acquisition of new methods has to be paid for, as well as our highly qualified staff, "he says. "For example, the DRK was the first institution to introduce PCR-based virus testing of blood donations in Germany."

Paid donations also occur in France and Austria. Meanwhile, Holland has obeyed EC rules and has become self-sufficient in donated blood. It's low number of hemophiliacs infected with HIV at the beginning of the AIDS epidemic has been attributed to this action.

Ellen Peerenboom, Cologne

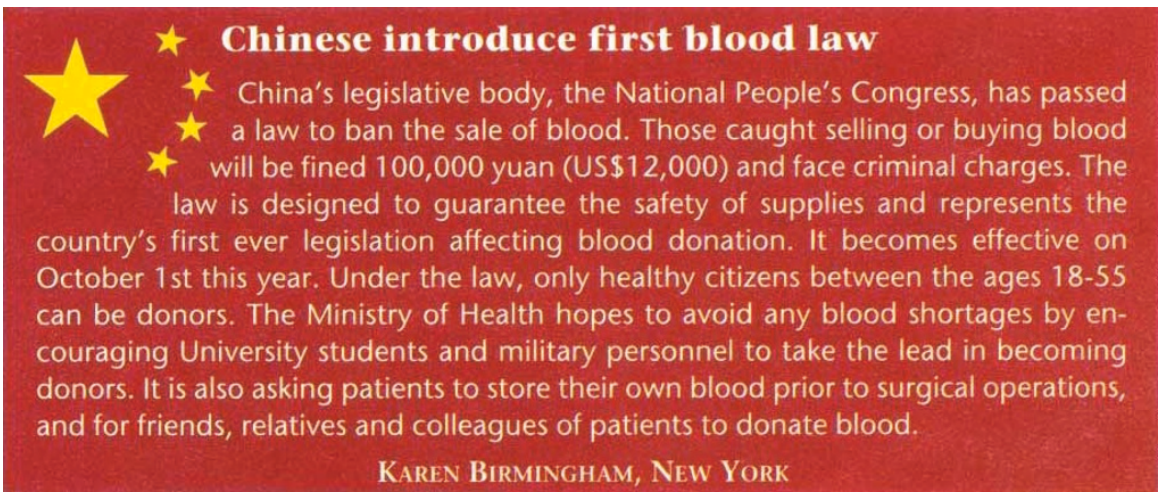

